\title{
Waste management and the role of waste administrators in Selangor, Malaysia
}

\author{
S. M. Kamaruddin ${ }^{1} \&$ D. B. Omar ${ }^{2}$ \\ ${ }^{I}$ Department of Geography, University of Canterbury, New Zealand \\ ${ }^{2}$ Faulty of Architecture, Planning \& Surveying, \\ Universiti Teknologi Mara, Malaysia
}

\begin{abstract}
This study highlights the perceptions of waste administrators regarding their main roles and responsibilities, efforts in promoting recycling or waste minimisation and awareness to the problems or constraints they face. Public waste administrators are actors in a waste management system and are often involved in initiating community activities, making decision and implementing policies, which should benefit the communities and the environment. They help to facilitate recycling campaigns in the hope that this will increase awareness and prompt the public to practice sustainable waste management behaviour. However, studies conducted in Malaysia reveal that there is still low public participation in recycling, indifference of the public towards waste minimisation effort and no clear guidelines on effective ways for administrators to conduct effective people based approaches. The lack of enforcements for recycling is also perceived to contribute to the lack of participation from the public. However, this study finds that the administrators are more enthusiastic about school communities participating in recycling programmes as compared to recycling activities run by other volunteers in the community. Administrators perceive that recycling effort should be the responsibility of each individual but the lack of commitment from the public in general to participate, misuse of recycling infrastructure, financial constraints and the absence of proper guidelines hamper many programmes sustainability. Generally, their main concern is to ensure waste is collected and the works monitored while communities should champion these activities with minimal interventions from the authority.
\end{abstract}

Keywords: waste administrators, recycling, waste minimisation, public participation, financial constraints. 


\section{Introduction}

Studies indicate that increasing population, a rapid urbanisation process, economic growth and rising personal consumption in developing countries, including Malaysia, lead to a rise in solid waste generation [1-4]. The average annual urban growth rate of 4.82 percent for Malaysia [5] implies a rise in discarded waste volume. The local authorities and waste management consortia have to handle approximately 17,000 tonnes of municipal solid waste everyday throughout the country where approximately 98 percent of the total waste goes to landfills [6]. This places pressure on the environment for more landfill to contain the waste. The national average of waste generated in the urban areas is at 1.7 per $\mathrm{kg}$. per person per day [4] and is close to that of major high-income developed countries economies [7]. The rising waste leads to more costs for collecting, handling, treating and storing from households to landfills while the consequences of improper management are environmental and quality of life degradation [8]. Malaysians, especially those who do not recycle, view recycling as the primary responsibility of the local authority [9].

Very few researches highlighted the constraints faced by and perceptions of the authorities $[10,11]$ that could lead to ineffective recycling programmes. Municipal officials' dominance of 'pervasive patronage and clientalism' [12] in delivery of a basic service had generated an unhealthy mindset among the public that all waste management problems are the sole responsibility of the municipalities. The public were more motivated to partner local authorities in community waste recycling or composting activities with financial, technical assistance and market support from the authorities [13]. Partnerships between different actors are extensively promoted in the literature as a way to a more integrated and efficient waste management $[14,15]$. In addition, for any recycling programmes to sustain, local authorities should formulate regulations, policies and programmes, develop strategic planning with goals, implementation and monitoring [8, 16]. Unfortunately in Malaysia, the role of municipalities in recycling activities is often minimal where these activities are carried out on an informal and voluntary basis $[1,8,16]$ with no proper guidelines, regulations or strategic planning.

This paper highlights some views of waste administrators on waste management and their efforts to promote public participation in recycling efforts specific to Selangor.

\section{Waste management in Selangor, Malaysia}

In Malaysia, the responsibility of municipal waste management lies with the local government authorities. In most urban centres waste generated from households is required to be placed in waste bags in bins in front of their homes (kerbside) and private collectors would collect the waste thrice a week. About 48 percent of waste in Malaysia is organic and the rest inorganic [16]. There is no regulation to the type of waste bag and most households utilise or reuse the plastic grocery bags to store waste. Householders pay an annual house 
assessment, which indirectly pays for the collection services [7]. Many have the attitude that having paid the tax, all responsibilities lie with the local authorities $[8,9]$. Selangor is the most developed state in Malaysia, with a population of over four million and a growth of 2.4 percent annually while the population projection for the year 2020 is 7.3 million [17]. There are eight districts in Selangor and twelve municipal councils or local authority.

Reports published by the Ministry of Housing and Local Malaysia Government (1999) revealed that Selangor's average waste volume was 2,375 tonnes per day or 15 percent of the national daily waste and was the highest compared to other states in Malaysia. The government initiated the 3R (Reduce, Reuse, and Recycle) campaign in year 2000 in response to a growing concern for the environment and the scarcity of suitable land as landfills. The campaigns objectives were to increase the public's awareness towards recycling in the belief that this will increase the rate of recycling practice [18]. Some urban areas in Selangor and Penang have recorded recycling percentage of 9-15 percent [1] but generally, Malaysians recycling rate is 5 percent [19].

\section{Research methodology}

This study aims to provide information about the views and expressed attitudes of waste administrators over waste management and the lack of public participation in community based recycling programmes in Selangor. It also proposes possible strategies for the administrators to consider towards reinforcing public participation in recycling activities. The researcher conducted unstructured interviews and asked broad, open-ended questions in which the perceptions or views of the waste administrators were recorded using a tape recorder. Prior to conducting each interview, a letter requesting information and for conducting interview of public officials was prepared and submitted to the specific mayor (city councils) or Yang di Pertua of a municipality (town and district councils). This is normal procedure if one were to request information from public authorities in Malaysia. The following questions were posed:

1. Which department within the municipality is responsible over the management of waste? What are the duties involved? Are there any brochures or pamphlets and organisation structure available?

2. What are the main issues affecting the department in their daily tasks?

3. Are there any programmes involving the municipality and the communities towards minimising waste that is $3 \mathrm{R}$ and composting? What are some of the obstacles faced?

4. Who are other actors that the municipality are aware of in waste recycling activities and is there any partnerships involved?

Upon receiving the letter of request, the respective mayor or Yang di Pertua would then minute the letter and assign the Director or Head of the relevant department to assist the enquirer in any possible means. It is expected that the municipality would reply to the letter usually within a month or maybe longer, with feedback. However, due to time constraints, a phone call to the administrators for an earlier interview met with some success. Seven out of 
twelve officials agreed to be interviewed. Each local authority delegates the task of solid waste management that is municipal waste to a department in the Local Authority either to the Department of Urban Services and Environment or the Department of Urban Services, Health and Environment with one municipality delegating this to the Department of Landscape and Urban Services. Each municipality does not impose requirements for households to recycle. With the exception of one municipality, hawkers or small business food stalls are not required to separate the wet waste (or food waste). Only one municipality has a programme (in joint venture with a Danish organisation) to provide bins for wet food waste to the stall or hawkers food court which are collected and sent for composting production. The main obstacle was to find ways to increase the volume of compostable waste thus, participation from the stall operators is necessary.

The interviews with the seven waste administrators were conducted at the administrators office and tape recorded to obtain verbatim transcripts and later transcribed. The responses were further grouped into two categories of investigation. The first category highlights their perception on waste management, which states what they believe to be the benefits or issues affecting waste management in general while the second category highlights is their attitude towards solving the issues or managing the situation. The statements and views from the officials in regards to the particular question, were further categorised as either having a positive outlook or otherwise.

\section{Results and discussions}

The officials perceive that the practice of separating waste at home, community recycling activities and the involvement of other actors in waste management are issues which affect different degrees of involvement and level of participation by the society.

\subsection{Responsibility}

They perceive that their role is mainly to monitor the private contractors work while uplifting the social obligation of ensuring the cleanliness of the environment within the municipality's boundary. Although the bulk of collection work is the responsibility of the contractor, complaints of inefficient collection services are directed to the municipality to resolve the problem. The complaint has to be investigated and if proven true, the authorities will issue notice to the contractors resulting in a decrease in the service payments as a penalty.

\subsection{Separating of waste}

The administrators view that there are many social and environmental benefits from separating waste at home but because there is no regulation to enforce this, therefore, most households do not practice it. They are aware that there was a pilot kerbside recycling programme implemented within selected neighbourhoods but that these programme have ceased to continue, due partly to 
a waning interest from the public and financial constraints faced by the municipality. They view that only those who are interested and aware of the benefits of recycling to the environment or given financial incentives will separate waste while the majority of the public, who are not aware or concerned, will not practice separation of waste [7]. Also, it was found that the main reason given by those who did not separate waste was because they did not have any facility to separate waste.

\subsection{Recycling programmes and alliance with other actors}

Each municipality has plans and programmes with communities about recycling. For example, all local councils have campaigned, helped install infrastructure such as the three coloured recycling bins at certain strategic locations and produced pamphlets but the general public has yet to fully utilise these. The general perception by the authorities is that communities are 'slow' to act on recycling matters and the attitude of the municipal administrators is to allow more time for the public to be familiar with recycling.

The administrators perceive that recycling campaigns do help to increase the awareness of the community towards recycling but acknowledge that the public may not actually practice recycling. However, the administrators all agree that the most successful recycling programmes, based on the volume of recyclables collected and participation rate, are programmes organised at schools community such as SMART (Start Managing All Resources Today) Rangers which is in partnership with Global Environment Centre a non-profit organisation while recycling competitions with financial prizes continue to attract both corporate sponsors and participation of thousands of schoolchildren nationwide annually. Informal recycling efforts organised by non profit organisations and religious associations, although not many, were also quoted by the administrators as being active.

One municipality achieved very encouraging participation from the public after initiating a 'pay for garbage' scheme, but the programme was cancelled after a few months due to lack of finance that was borne by the municipality. There is no evaluation of the impact of this programme to the environment, recycling or participation rate but the programme was publicised in the national and local newspapers of Starmetro, 14 $4^{\text {th }}$ January 2008 and Kosmo, 27 $7^{\text {th }}$ April 2007 as successful in reducing litter within the locality.

With the exception of one municipality, hawkers or small business food stalls are not required to separate the wet waste (namely food waste). The one municipality which has a programme (in joint venture with a Danish organisation) provide bins for wet food waste to the stall or hawkers food court which are then collected and sent for composting production. The main obstacle was finding ways to increase the volume of compostable waste thus, participation from all stall operators is deemed necessary. 


\subsection{Itinerant buyers}

Most administrators perceive that informal itinerant buyers of recyclables are beneficial as they help reduce the amount of waste that would have been sent to the landfills. Generally, the buyers have a unique way of calling out to residents for old newspapers using the phrase 'old newspapers, suratkhabar lama'. They are popular to many urban households and will collect from door to door and normally pay a small sum of between one to two Ringgit Malaysia for a weeks worth of old newspapers. However, administrators perceive that these buyers can be a form of 'competition' to the formal contractors and their staff who would otherwise earn some income from the sale of recyclable materials.

\subsection{Attitudes of waste administrators}

The general attitude of the waste administrators regarding public participation in waste management can be regarded as positive due to their optimism that the public would change towards improved household waste practice given more time, continuous education campaigns and increasing awareness. They are more optimistic about the recycling programmes currently ongoing at almost all schools in Selangor than on other voluntary run community programmes although they view any involvement by them as an added responsibility.

The perceived responses from the administrators also implied that political and power influences play a significant role in many decision making. The waste administrators' expectation that sponsorships of programme are often (and currently) initiated by more established corporations or foreign aids, could also downplay the potential of partnering with smaller and local businesses. They expressed a view that their involvement in community waste minimisation activities is an 'added task' and the attitude that there should be minimal intervention of waste administrators or authorities in initiating or implementing recycling programmes are equivocal. On the one hand, setting up pilot kerbside recycling programmes and continuous organising of competitions in schools to raise awareness are positive efforts by the authorities in response to public's expectations.

\section{Conclusions}

Co-operation and public participation are required to ensure this complexity is manageable and benefits the environment. However, although the public participate in various waste minimisation activities, mostly voluntarily, as evidenced from reports in the media, published studies and through personal observations, Malaysians recycle only a minimal 5 percent while generating a considerable $1-1.5 \mathrm{~kg}$ of waste per person daily of which at least half of this waste can be recycled and diverted from the landfill [16]. Most of the waste ends up in unsanitary dumping landfills which further creates an environmental problem like leachate while consuming public lands for landfills which could 
otherwise have been for other more environmentally friendly uses such as parks or forest conservation areas.

Successful programmes that attract a good turn out or participation from the public seem to be the 'gotong royong' or neighbourhood cleanups organised once every three or six months or when there is serious health issue affecting the locality, for instance the incidence of the dengue fever. Another successful programme perceived and expressed by the administrators were recycling programmes organised by the school communities. Unsustainable and short lived programmes highlighted by them were the pilot kerbside recycling targeted at limited neighbourhoods, one 'pay for garbage' programme and setting up of recycling bins at locations that were thought to be strategic but proved otherwise.

The low participation rate and volume of recyclables were perceived by the administrators to be attributed to the communities' lack of awareness, interest and general apathy attitude while from the economic context, they quote financial constraints. These perceptions have not discouraged the public waste administrators' optimism towards continuing their support to the school communities recycling programmes. The programmes, which commonly initiate from government's directives or memorandums, are implemented by the students and the parents and teachers associations and perceived by the authorities to be successful as indicated by the volume of recyclables collected and the number of participants. They perceive that the school communities are more organised and have an action plan suited for their purpose towards waste minimisation. One of the success factors identified by the administrators was the involvement of established corporations or organisations who provided the financial incentives or rewards through competitions held among schools. The local municipality with the mayor's support include launching the campaign or the competition which usually is publicised through the media and press conferences. This strategy of involving different actors from different institutions; that is the school communities, the local authority and the business sector or non governmental organisations, has also been successful in neighbouring Thailand [11]. However, there has yet to be a comprehensive and systemic research or evaluation of the success of the schools recycling programme in Malaysia.

The role of the informal itinerant buyers and their potential impacts, whether they help promote and encourage households and other communities to recycle, or does provide employment opportunities have not been fully investigated or researched [14]. Waste administrators in this study however, perceive that these actors do provide the convenience for households to participate in recycling activities with their door to door collections. However, there needs to be further systemic evaluation of the social and economic impacts or contributions of other actors such as nongovernmental organisations or foreign aid involvement with the public and to what extent they can encourage public to practice recycling or other waste minimisation practices.

The general public and households still need to be educated on how to separate waste properly $[11,21]$ and effective implementation of public education strategies and methods must tailor to the target audiences [2, 9, 20]. The strategies implemented that included the public are commendable but to 
sustain the public's participation, within the traditional socio political context, the administrators should continuously understand the changing communities needs, the socio-psychological and economic influences underlying communities behaviour and devise an ongoing and relevant plan of action with continuous feedbacks and communication from the communities and all actors. Waste administrators as policy makers, traditional public service providers, and who are in part accountable for the well being of the environment as they themselves perceive to be, need to build their own capacity, acquire effective management skills, reflect and learn the underlying impacts of their efforts, successes or failures.

\section{References}

[1] UNDP. Malaysia developing a solid waste management model for Penang, Kuala Lumpur: United Nations Development Programme (UNDP), Malaysia, 2008.

[2] Haron, S.A., Paim, L., \& Yahya, N., Towards sustainable consumption: an examination of environmental knowledge among Malaysians, International Journal of Consumer Studies, 29(5), 426-436, 2008.

[3] Mongkolnchaiarunya, J., Promoting a community-based solid-waste management initiative in local government: Yala Municipality, Thailand, Habitat International, 29(1), 27-40, 2005.

[4] Kathirvale, S., Muhd Yunus, M.N., Sopian, K., \& Samsuddin, A. H., Energy potential from municipal solid waste in Malaysia, Renewable Energy, 29(4), 559-567, 2004.

[5] Government of Malaysia, Department of Statistic, 2002.

[6] Fauziah, S.H., Simon, C., \& Agamuthu, P., Municipal solid waste management in Malaysia - possibility of improvement? Malaysian Journal of Science, 23(2), 61-70, 2004.

[7] Othman, J., Household preferences for solid waste management in Malaysia (No. 2002-RR8): Economy and Environment Program for Southeast Asia (EEPSEA), 2002.

[8] Isa, M.H., Asaari, F., Ramli, N.A., Ahmad, S., \& Tan, S.S., Solid waste collection and recycling in Nibong Tebal, Penang, Malaysia: a case study, Waste Management \& Research, 23, 565-570, 2005.

[9] Hong, M.C., \& Narayanan, S., Restoring the shine to a pearl: recycling behaviour in Penang, Malaysia, Development and Change, 37(5), 11171136, 2006.

[10] Bolaane, B., Constraints to promoting people centred approaches in recycling, Habitat International, 30(4), 731-740, 2006.

[11] Suttibak, S., \& Nitivattananon, V., Assessment of factors influencing the performance of solid waste recycling programs, Resources, Conservation and Recycling, 53(1-2), 45-56, 2008.

[12] Chanisada Charuvichaipong, \& Edsel Sajor, Promoting waste separation for recycling and local governance in Thailand, Habitat International, 30(3), 579-594, 2006. 
[13] Colon, M., \& Fawcett, B., Community-based household waste management: Lessons learnt from EXNORA's 'zero waste management scheme in two South Indian cities', Habitat International, 30, 916-931, 2006.

[14] Baud, I., Grafakos, S., Hordijk, M., \& Post, J., Quality of life and alliances in solid waste management: contributions to urban sustainable development, Cities, 18(1), 3-12, 2001.

[15] Klundert, A.V.D., \& Anschiitz, J., The sustainability of alliances between stakeholders in waste management, working paper for UWEP/CWG30 May 2000 - Draft, 2000.

[16] Hassan, M.N., Chong, T.L., Rahman, M., Salleh, M.N., Zakaria, Z., \& Awang, M., Solid waste management in Southeast Asian countries with special attention to Malaysia, The Sardinia 2001, Eighth International Waste Management and Landfill Symposium Cagliari, Italy, 2001.

[17] Selangor, J.P.B.D., Rancangan Struktur Negeri Selangor (Selangor 2020 Structure Plan prepared under Section 8, Act 172 (Town and Country Planning Act 1976)), 2000.

[18] Dasimah Bt Omar, \& Nazri Osman, Waste management in the city of Shah Alam, Malaysia, WIT Transactions on Ecology and the Environment, vol. 109, 605-611, Southampton, WIT Press, 2008.

[19] Troschinetz, A.M., \& Mihelcic, J.R., Sustainable recycling of municipal solid waste in developing countries, Waste Management, 29(2), 915-923, 2009.

[20] Agamuthu, P., Solid waste: principle and management: University of Malaya Press, Kuala Lumpur, 2001.

[21] Troschinetz, A.M., \& Mihelcic, J.R., Sustainable recycling of municipal solid waste in developing countries, Waste Management, 29(2), 915-923, 2009. 